Article

\title{
Toxicity Characterisation of Gambierdiscus Species from the Canary Islands
}

\author{
Araceli E. Rossignoli $\left.{ }^{1} * \mathbb{(}\right)$, Angels Tudó ${ }^{2}$, Isabel Bravo ${ }^{1}$, Patricio A. Díaz ${ }^{3}{ }^{\circledR}$, Jorge Diogène ${ }^{2}$ and \\ Pilar Riobó ${ }^{4}$ \\ 1 Instituto Español de Oceanografía, Centro Ocenográfico de Vigo, Subida a Radiofaro 50, 36390 Vigo, Spain; \\ isabel.bravo@ieo.es \\ 2 IRTA, Ctra. Poble Nou, km. 5.5, 43540 Sant Carles de la Ràpita, Spain; angels.tudo@irta.cat (A.T.); \\ jorge.diogene@irta.cat (J.D.) \\ 3 Centro i mar \& CeBiB, Universidad de Los Lagos, Casilla 557, Puerto Montt, Chile; patricio.diaz@ulagos.cl \\ 4 Department of Photobiology and Toxinology of Phytoplankton, Instituto de Investigaciones Marinas, CSIC, \\ Eduardo Cabello 6, 36208 Vigo, Spain; pilarriobo@iim.csic.es \\ * Correspondence: araceli.escudeiro@ieo.es; Tel.: +34-986492111; Fax: +34-986498626
}

Received: 20 December 2019; Accepted: 17 February 2020; Published: 21 February 2020

\begin{abstract}
In the last decade, several outbreaks of ciguatera fish poisoning (CFP) have been reported in the Canary Islands (central northeast Atlantic Ocean), confirming ciguatera as an emerging alimentary risk in this region. Five Gambierdiscus species, G. australes, G. excentricus, G. silvae, G. carolinianus and $G$. caribaeus, have been detected in macrophytes from this area and are known to produce the ciguatoxins (CTXs) that cause CFP. A characterization of the toxicity of these species is the first step in identifying locations in the Canary Islands at risk of CFP. Therefore, in this study the toxicity of 63 strains of these five Gambierdiscus species were analysed using the erythrocyte lysis assay to evaluate their maitotoxin (MTX) content. In addition, 20 of the strains were also analysed in a neuroblastoma Neuro-2a (N2a) cytotoxicity assay to determine their CTX-like toxicity. The results allowed the different species to be grouped according to their ratios of CTX-like and MTX-like toxicity. MTX-like toxicity was especially high in G. excentricus and G. australes but much lower in the other species and lowest in G. silvae. CTX-like toxicity was highest in G. excentricus, which produced the toxin in amounts ranging between $128.2 \pm 25.68$ and $510.6 \pm 134.2 \mathrm{fg} \mathrm{CTX1B}$ equivalents (eq) cell ${ }^{-1}$ (mean $\pm \mathrm{SD}$ ). In the other species, CTX concentrations were as follows: G. carolinianus (100.84 \pm $18.05 \mathrm{fg}$ CTX1B eq cell $\left.{ }^{-1}\right), G$. australes $\left(31.1 \pm 0.56\right.$ to $107.16 \pm 21.88 \mathrm{fg} \mathrm{CTX} 1 \mathrm{~B}$ eq cell $\left.^{-1}\right)$, G. silvae $\left(12.19 \pm 0.62\right.$ to $76.79 \pm 4.97 \mathrm{fg}$ CTX1B eq cell $\left.{ }^{-1}\right)$ and $G$. caribaeus ( $<$ LOD to $90.37 \pm 15.89 \mathrm{fg}$ CTX1B eq cell ${ }^{-1}$ ). Unlike the similar CTX-like toxicity of $G$. australes and $G$. silvae strains from different locations, G. excentricus and G. caribaeus differed considerably according to the origin of the strain. These differences emphasise the importance of species identification to assess the regional risk of CFP.
\end{abstract}

Keywords: Canary Islands; ciguatera; ciguatoxins; erythrocyte lysis assay; maitotoxins; neuroblastoma cytotoxicity assay

Key Contribution: The erythrocyte lysis assay allowed the analysis of a large number of Gambierdiscus strains for the presence of compounds with MTX-like toxicity and therefore the potential to cause CFP, which in the Canary Islands is a relevant concern. MTXs-like toxicity levels were highest in G. excentricus and G. australes species. According to the results of the ELA and the N2a assay, G. excentricus has the greatest potential to cause CFP in the Canary Islands. 


\section{Introduction}

Gambierdiscus is a genus of marine benthic dinoflagellates that produces maitotoxins (MTXs) and ciguatoxins (CTXs) [1-3]. These cyclic polyether neurotoxins are among the five most potent natural toxins isolated to date [4]. Because they accumulate in coral reef fish, they can be transferred through the marine food web [5-8]. In fact, CTXs are the main toxins responsible for ciguatera fish poisoning (CFP) [9], a clinical syndrome caused by eating CTX-contaminated fish. The risks to human health related to the consumption of these toxins in fish have been assessed by the EU Food Safety Authority (EFSA) Panel on Contaminants [10]. CFP is widespread in tropical and sub-tropical marine areas, including the Caribbean Sea, Indian Ocean, Polynesia and other areas of the Pacific Ocean [11]. However, over the past decade, an increase in the incidence of CFP in areas where ciguatera is endemic [12-14] and several outbreaks of ciguatera in more temperate regions, such as Madeira [15-17] and the Canary Islands (NE Atlantic Ocean) [18], suggest an expansion of this disease is occurring.

The first reported CFP outbreak in the Canary Archipelago was described in 2004. Five people were affected [19]. Two additional episodes happened in 2008 causing the intoxication of 11 people [20]. Since then, several CFP episodes affected 113 people (Canary Government, 2017), [21,22]. Because of recurrent outbreaks, CFP has been designated as a notifiable disease in the Canary Islands since 2015 (Canary Government, 2017).

The main fish species involved in CFP in this area are amberjack (Seriola spp.), dusky grouper (Epinephelus marginatus) and Wahoo (Acantocybium solandri). The weight limits above which risks might occur are $14 \mathrm{~kg}, 17 \mathrm{~kg}$ and $35 \mathrm{~kg}$ respectively. Although CFP occurs when toxic fish is ingested, CTXs are produced by microalgae belonging to Gambierdiscus genus.

In the Canary Islands, ciguatera outbreaks have been related to Gambierdiscus species, including G. australes, G. excentricus, G. silvae, G. carolinianus and G. caribaeus [23], all of which have been isolated from macrophytes. An expansion of the Gambierdiscus distribution toward higher latitudes has been attributed to the increase in the ocean temperature caused by climate change.

CTXs are selective activators of voltage-dependent $\mathrm{Na}^{+}$channels in cells [24-27] whereas MTXs are water-soluble and alter the ion transport systems, causing an increase in free intracellular $\mathrm{Ca}^{2+}[28-32]$. Although highly toxic [33], MTXs do not induce CFP, because of their low oral potency and inability to accumulate in the muscle tissue of fish [7]. The extensive literature survey by Munday [34] found no published records of the oral toxicity of MTX and the only evidence of MTX accumulation in fish liver and viscera recorded before 2014 came from two studies published in the 1970s [35,36]. Whether MTX can cause CFP via other routes remains to be investigated.

Numerous methodologies based on different approaches (e.g., toxicological symptoms, antibody recognition, mass spectrometry, etc.,) have been developed for the detection of CTX and MTX, but their use is often problematic (due among other things to, antibody cross-reactivity for CTX from different origins). In addition to better sampling procedures to allow an efficient extraction and concentration of the toxins, improved clean-up procedures to remove impurities that negatively impact sample analyses are needed. From an analytical perspective, the complexity of the sample matrix, the very low levels of toxin detected, and the lack of reference toxin material have greatly hampered the development of reliable methods for CTX and MTX determinations. Moreover, there are currently no chemical methods with the required sensitivity and specificity to rapidly monitor either of these toxins [37], and detection by LC-MS/MS [38] may lead to misidentifications. Consequently, to date, CTXs have been identified only in a few Gambierdiscus strains, i.e., those of G. toxicus [39], G. polynesiensis [2], G. ruetzeri [40], G. pacificus [3], G. silvae and G. excentricus [41]. In the absence of a rapid, cost-effective and reliable screening test for CTXs, health authorities around the world have relied on guidelines aimed at preventing high-risk fish species and fish life stages from entering the commercial market to reduce the risk of CFP [42]. This strategy takes into account that CTXs can bioaccumulate over time, such that older and larger fish are more likely to be contaminated with higher levels of CTXs. However, few studies have directly examined the relationship between fish size and the presence of 
CTX in individual fish species [43]. A further problem is that there are no accredited methods for the analysis of CTXs and MTXs in fish samples.

A previous study showed that toxicity is more closely related to genetics rather than to environmental (temperature, ph and salinity) factors [44]. Among Gambierdiscus species in the Canary Islands, both G. excentricus [45,46] and G. australes [47] are known to produce high levels of CTX. However, information on other regional members of this genus is scarce. Therefore, in this study we characterised the relative toxicity of 63 Gambierdiscus strains of the five Gambierdiscus species described in the Canary Islands thus far (Figure 1). An erythrocyte lysis assay (ELA) based on the method of Holland et al. [48] was performed to determine and compare MTX production by the tested strains. In addition, CTX production by the 20 most representative strains was assessed using the neuroblastoma cell-based assay (Neuro-2a assay). Compared to instrument-based methods, the ELA and the Neuro-2a assay are more sensitive and do not require precise standards, since both assess the effect of the toxins on cells. Consequently, the assays have been widely used to detect MTX-like and CTX toxicities, respectively. The particular advantages of the ELA as a screening assay is that it requires relatively little starting material and is fast, highly reproducible and cost-effective.

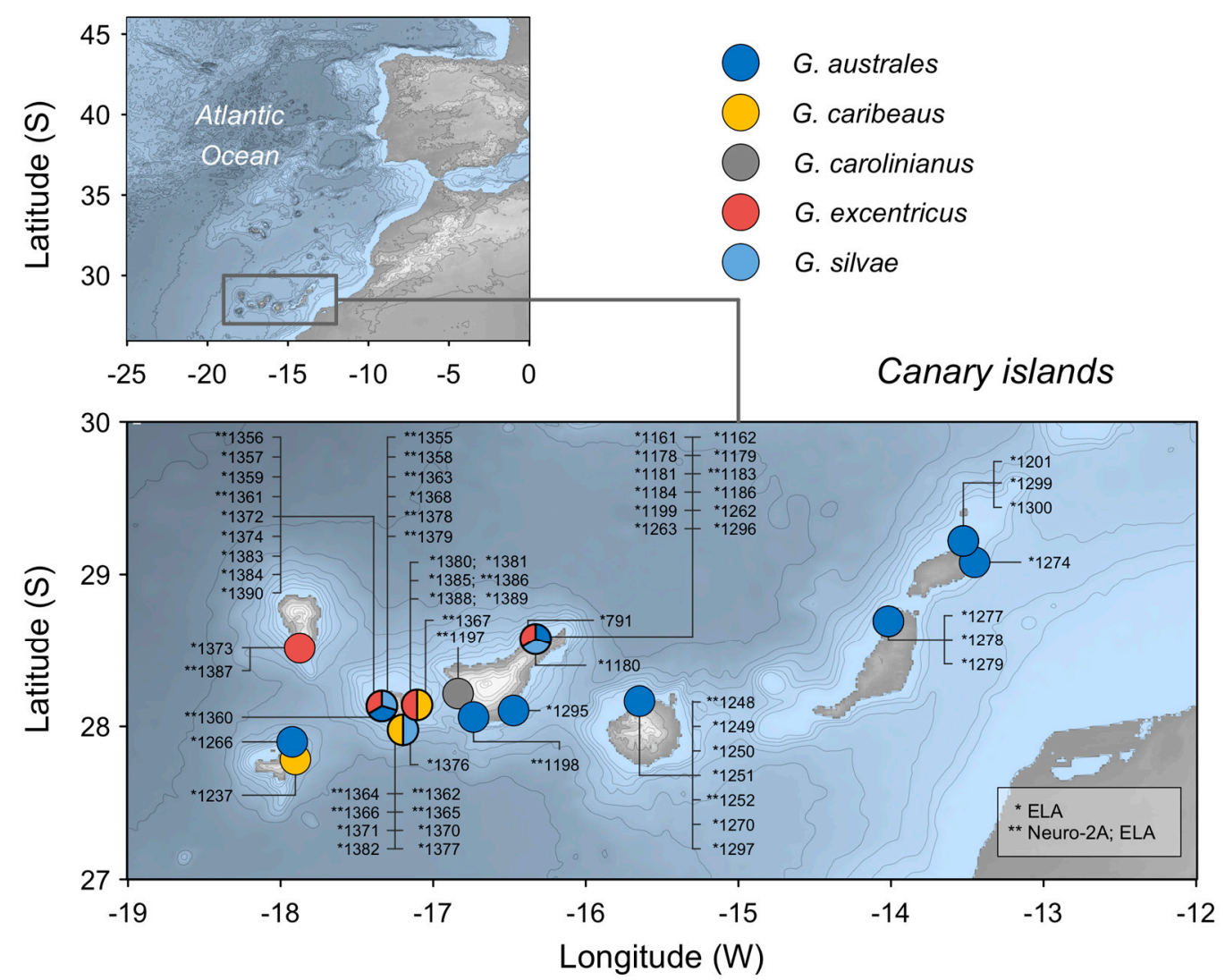

Figure 1. Gambierdiscus strains from Canary Islands examined in this study. * Analysed using the erythrocyte lysis assay (ELA); ${ }^{* *}$ analysed using both the ELA and the Neuro-2a cell assay.

\section{Results}

\subsection{Screening of CTX-Like Toxicity Using the Neuro-2a Assay}

As predicted, when neuroblastoma cells were exposed to CTX1B standard they did not exhibit toxicity signals $(>80 \%)$ in $\mathrm{O} / \mathrm{V}-$ conditions. Conversely when neuroblastoma cells were exposed to $\mathrm{CTX} 1 \mathrm{~B}$ in $\mathrm{O} / \mathrm{V}+$ treatment, the cell viability exhibited a typical sigmoid dose-response curve. The $\mathrm{IC}_{50}$ mean for the CTX1B standard was $2.33 \pm 1.30 \mathrm{pg}^{\mathrm{CTX}} 1 \mathrm{~B} \mathrm{~mL}^{-1}$. The crude extracts $(\mathrm{CE})$ of nineteen canaries strains (Figure 1) and the Cuba strain VGO1397 were tested with the neuro-2a assay. CTX-like 
toxicity was attributed to microalgal extracts when the addition of a sample extract to neuroblastoma cells exposed to $\mathrm{O} / \mathrm{V}+$ treatment resulted in $20-80 \%$ viability decrease. However, the addition of the same extract to neuroblastoma cells exposed to $\mathrm{O} / \mathrm{V}$ - treatment did not affect the cell viability $(>80 \%$ viability). Moreover, enhanced mortality in the wells in $\mathrm{O} / \mathrm{V}-$ conditions were observed $(<80 \%$ of viability) for some strains. This indicates the presence of non-specific toxic compounds other than sodium channel activators that apparently is according to the results of the ELA analysis. These non-specific effects are shown in Figure 2 showing the dose-response curve of 20 Gambierdiscus strains tested in the Neuro-2a cellular assay.

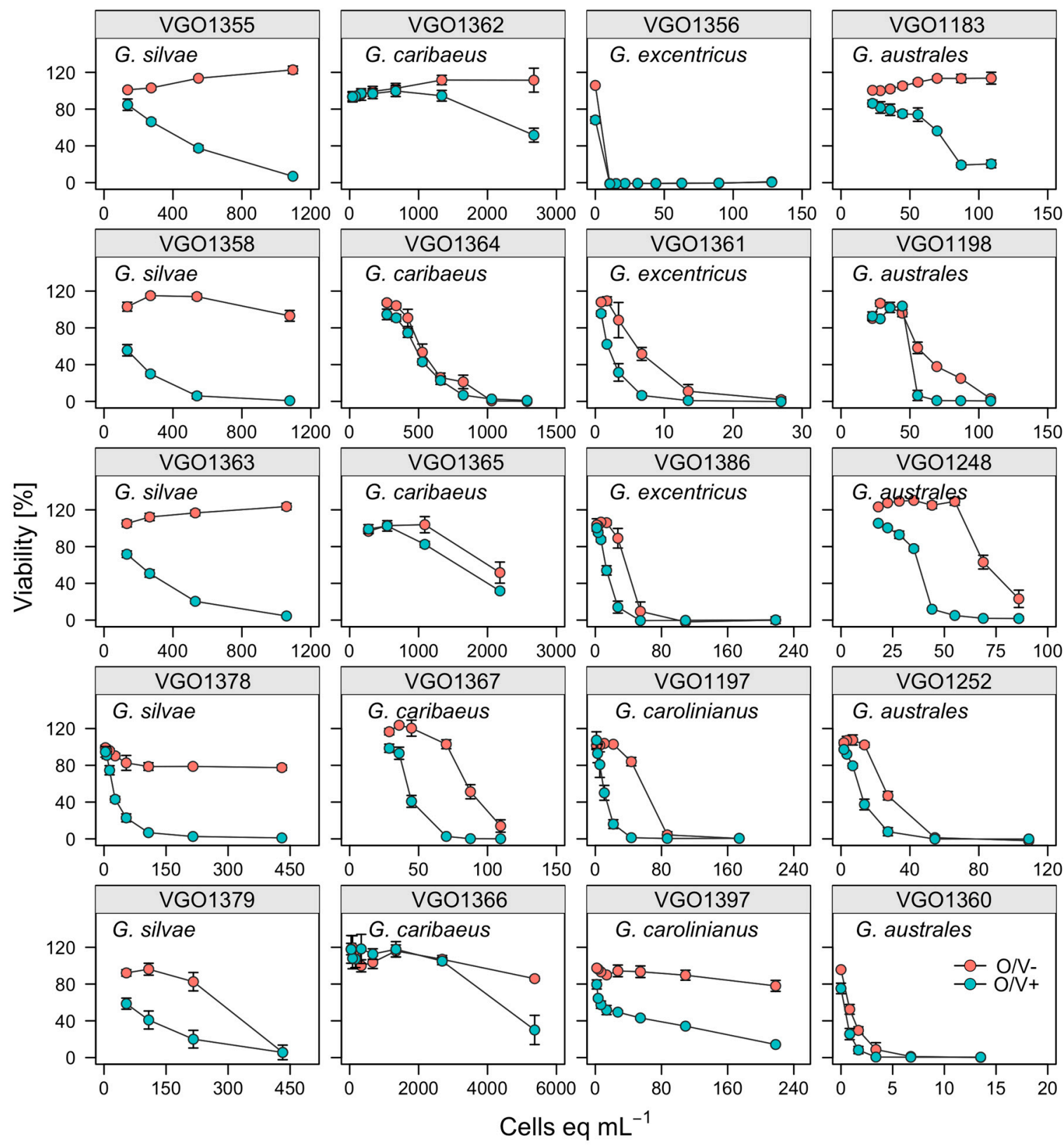

Figure 2. Dose-response curves of treated $(\mathrm{O} / \mathrm{V}+$ green symbol) and non-treated $(\mathrm{O} / \mathrm{V}-$, red symbol) neuroblastoma cells $24 \mathrm{~h}$ after their exposure to extracts prepared from 20 Gambierdiscus strains.

Neuro-2a cells, exposed to G. excentricus extracts (VGO1356, VGO1361, VGO1386) at concentrations ranging between 10.5 and 54 microalgal cells eq $\mathrm{mL}^{-1}$ with $\mathrm{O} / \mathrm{V}-$, showed a very low viability $(<20 \%)$. The activity of G. australes extracts presented higher variability in toxicity responses as compared to 
G. excentricus. Four extracts (VGO1198, VGO1248, VGO1252, VGO1360), at concentrations ranging between 80 and 100 cells $\mathrm{mL}^{-1}$ in $\mathrm{O} / \mathrm{V}$-conditions, affected the cell viability highly. However extract (VGO1183) at the same concentrations and conditions did not affect the cell viability. This variability in $\mathrm{O} / \mathrm{V}-$ conditions could be observed also in G. caribaeus and G. silvae extracts. For G. caribaeus, 3 out of 5 strains affected Neuro-2a viability at levels ranging from 70 to 1000 cells eq $\mathrm{mL}^{-1}$ (VGO1364, VGO1365, VGO1367). For G. silvae, 1 out of 4 strains (VGO1379) affected Neuro-2a viability at approximately 500 cells eq $\mathrm{mL}^{-1}$ (Figure 2). For the other strains of G. caribaeus (VGO1366) and G. silvae (VGO1358), no signals of toxicity under $\mathrm{O} / \mathrm{V}$ - conditions appeared at 3000 cells eq $\mathrm{mL}^{-1}$ and 1000 cells eq $\mathrm{mL}^{-1}$, respectively (Figure 2).

A quantitative estimation of CTX-like toxicity was possible in only 16 of the 20 sample analysed, despite the very low cell viabilities $(<20 \%)$ in the O/V - treatments exposed to VGO1198 and VGO1360 (G. australes), VGO1356 (G. excentricus) and VGO1397 (G. carolininanus), the cell viability plots did not result in a sigmoidal curve (Figure 2). The results for the other strains are expressed as fg CTX1B eq cell $^{-1}$ (Figure 3). Among these strains, the highest levels of CTX-like toxicity (between $128.2 \pm$ 25.68 and $510.6 \pm 134.2 \mathrm{fg}$ CTX1B eq cell ${ }^{-1}$ ) occurred in response to G. excentricus extracts, followed by VGO1197 G. carolinianus extracts $\left(100 \pm 18.05 \mathrm{fg} \mathrm{CTX1B} \mathrm{eq} \mathrm{cell}^{-1}\right)$ and $\mathrm{G}$. australes and G. silvae extracts (from $31.1 \pm 0.56$ to $107.16 \pm 21.88$ and from $12.19 \pm 0.62$ to $76.79 \pm 4.97 \mathrm{fg} \mathrm{CTX} 1 \mathrm{~B}$ eq cell $^{-1}$, respectively) (Figure 3). The lowest toxicity occurred in response to extracts from the G. caribaeus strains (from below the detection limit (1.76) to $2.59 \pm 0.5 \mathrm{fg} \mathrm{CTX1B} \mathrm{cell}^{-1} \mathrm{eq}$ ) (Figure 3). However, G. caribaeus VGO1367, the only strain whose origin (La Gomera, San Sebastián-Playa la Cueva) differed from that of other strains of the same species (La Gomera Porto-Playa Santiago), had a high CTX-like toxicity (90.37 \pm

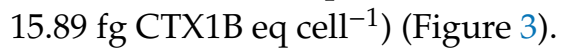

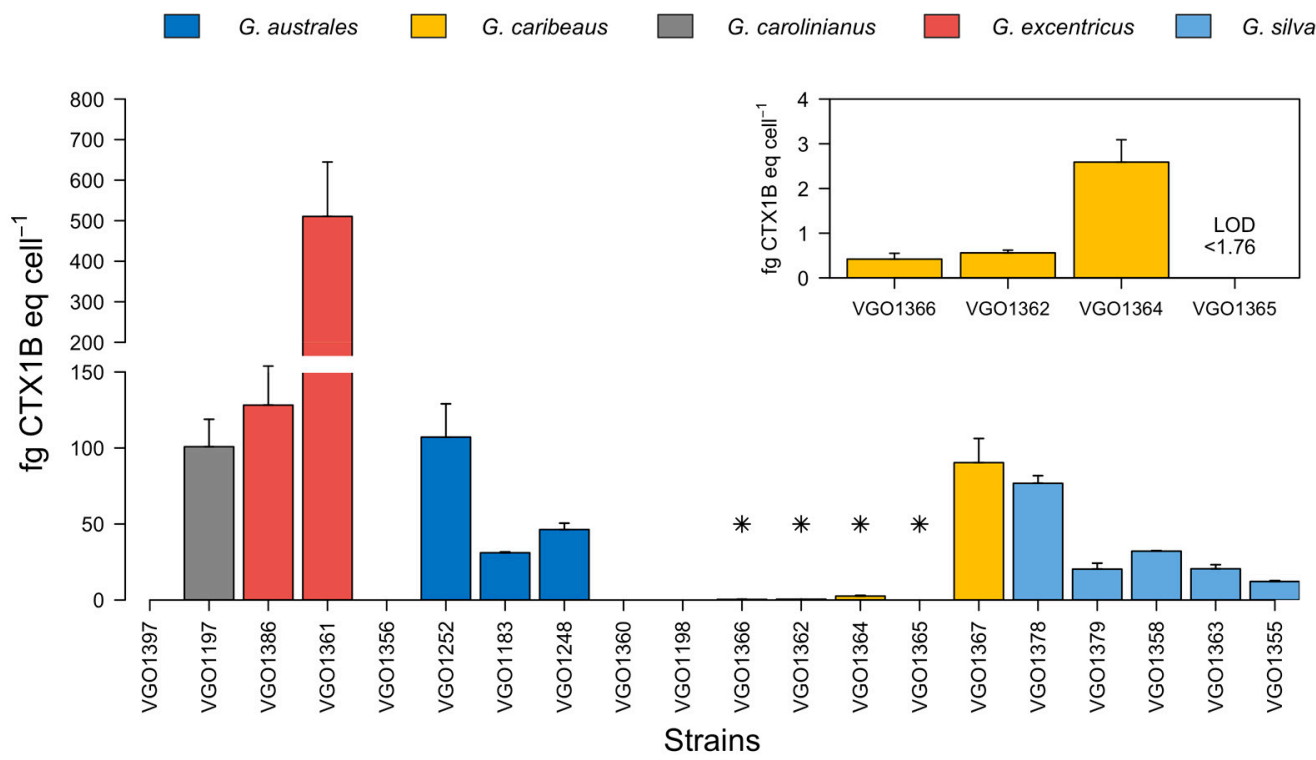

Figure 3. CTX-like toxicity expressed in femtograms of CTX1B equivalents per cells (fg CTX1B eq cell $^{-1}$ ) of Gambierdiscus strains as determined in a Neuro-2a cytotoxicity assay. Strains with the lowest concentrations are indicated by asterisks $\left(^{*}\right)$ and shown in the small bar plot in the inset. Strains VGO1397 (G. carolininanus), VGO1356 (G. excentricus), VGO1360 and VGO1198 (G. australes) could not be quantified. Bars in the columns represent the standard deviation.

\subsection{Toxicity Screening Using the Erythrocyte Lysis Assay}

The relationship between cell abundance and haemolysis (\%) for each strain of the five Gambierdiscus species (G. australes, G. caribaeus, G. carolinianus, G. excentricus and G. silvae) is shown in Figure 4A,B. Among the tested strains of $G$. excentricus, cell abundance correlated significantly with haemolysis ( $p<0.05 ; \mathrm{R}=0.67$, Figure $4 \mathrm{~B})$. The analysis of covariance (ANCOVA) showed the significant effects of 
cell abundance and Gambierdiscus species on the percent haemolysis (Table 1). There was no interaction between two explicative variables.
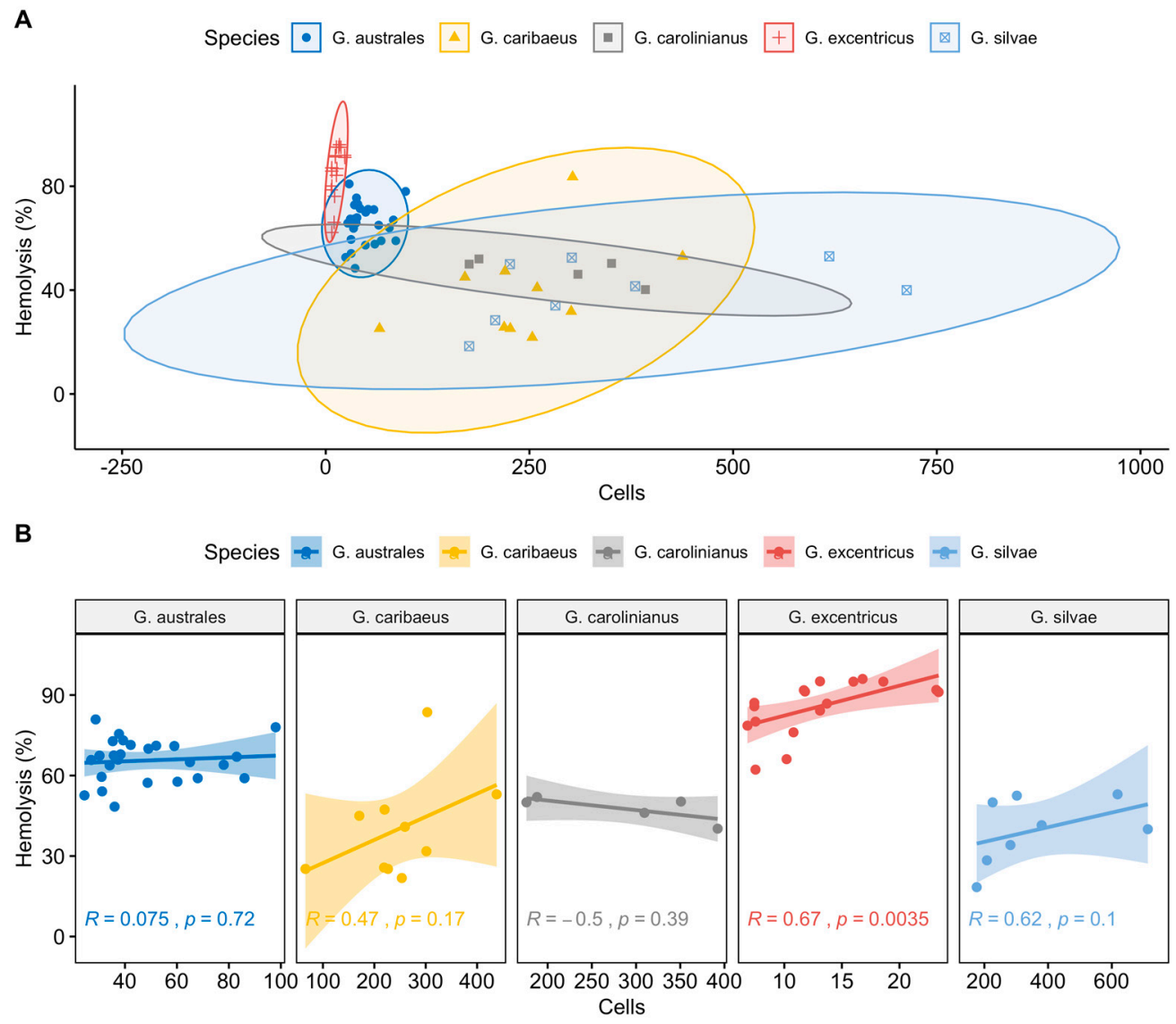

Figure 4. Scatter plot (A) and line regression (B) of the relationship between cell abundance and haemolysis (\%) for each Gambierdiscus strain. Ellipses and shaded areas in panels A and B represent the $95 \%$ confidence intervals. Correlation coefficients $(R)$ and $p$-values are indicated in each line regression plot.

Table 1. Analysis of covariance (ANCOVA) results of the effect of Gambierdiscus species and cells on haemolysis $(\%)$. Significant differences are indicated with asterisks $(*)$.

\begin{tabular}{ccccccc}
\hline Data & Df & Sum Sq & Mean Sq & F value & $p$ & \\
\hline Cells & 1 & 0.93 & 0.93 & 79.34 & $1.41 \times 10^{-12}$ & $* * *$ \\
Species & 4 & 1.08 & 0.27 & 22.95 & $1.53 \times 10^{-11}$ & $* * *$ \\
Residuals & 60 & 0.70 & 0.01 & & & \\
\hline
\end{tabular}

Post-hoc Tukey's H comparisons of the percent haemolysis induced by the five Gambierdiscus species showed significant differences, with higher MTX like toxicities associated with G. excentricus and G. australes than with G. caribaeus, G. carolinianus and G. silvae (Table 2). 
Table 2. Post-hoc Tukey's H comparisons of the haemolysis (\%) induced by five species of Gambierdiscus (G. australes, G. caribaeus, G. carolinianus, G. excentricus and G. silvae). Significant differences are indicated with asterisks $\left.{ }^{*}\right)$.

\begin{tabular}{cccccc}
\hline Species & Estimate & Std. error & t-value & $p$ & \\
\hline G. caribaeus-G. australes & -0.33 & 0.05 & -6.2 & $<0.001$ & $* * *$ \\
G. carolinianus-G. australes & -0.26 & 0.07 & -3.9 & 0.0018 & $* *$ \\
G. excentricus-G. australes & 0.21 & 0.03 & 6.17 & $<0.001$ & $* * *$ \\
G. silvae-G. australes & -0.37 & 0.07 & -5.34 & $<0.001$ & $* * *$ \\
G. carolinianus-G. caribaeus & 0.06 & 0.06 & 1.08 & 0.80 & \\
G. excentricus-G. caribaeus & 0.54 & 0.06 & 9.18 & $<0.001$ & $* * *$ \\
G. silvae-G. caribaeus & -0.04 & 0.06 & -0.78 & 0.93 & \multirow{2}{*}{ G. } \\
G.excentricus-G. carolinianus & 0.47 & 0.07 & 6.59 & $<0.001$ & $* *$ \\
G. silvae-G. carolinianus & -0.11 & 0.06 & -1.70 & 0.42 & \\
G. silvae-G. excentricus & -0.58 & 0.08 & -7.69 & $<0.001$ & $* * *$ \\
\hline
\end{tabular}

\section{Discussion}

The Canary Islands are a recent area of ciguatera endemicity [18]. Benthic dinoflagellates belonging to the Gambierdiscus genus, specifically those that could produce MTXs and CTXs, seem to be implicated in ciguatera outbreaks in the region and therefore the risk of seafood poisoning. Vulnerable fish species include Seriola spp. and Epinephelus spp.

Tools to assess the ciguatera risk in different areas based on the toxins detection should be fast and have a low detection limit. In addition they should be able to detect the different toxins analogues and derivatives. Neuroblastoma cell-based assay accomplishes very well the last two requirements. Neuroblastoma cell-based assay can detect the effect of CTXs and MTXs analogues at low concentrations [49-52] and also other possible novel toxins with the same effect on sodium channels [53]. The drawback of this is that it cannot attribute the CTX-like or MXT-like effect to one specific molecule [52]. For this, instrumental techniques such as LC-MS/MS or LC-HRMS are required. In the present study, the cell-based assay was applied as a first screening tool to be used for the higher risk species through the comparison of the strains composite CTX-activity and MTX-activity.

Two approaches to evaluate the toxicity of the extracts in neuroblastoma cells were used in this study. The first one is neuroblastoma cell viability evaluation in absence of ouabain and veratridine. Under this approach, cell death may not indicate the presence of a specific type of compound. This is called non-specific toxicity. MTXs production has been described in Gambierdiscus species [46,54,55]. The non-specific toxicity in the absence of ouabain and veratridine observed when testing Gambierdiscus extracts could indicate the presence of MTXs. In this case if CTXs or substances that provoke CTX-like activity were present, CTX-like toxicity could not be detected. The second approximation is the evaluation of the cell viability in the presence of ouabain and veratridine. In this case, the presence of substances affecting voltage gated sodium channels will result in cell death, therefore, CTXs or other analogues having a similar mechanism of action will enhance cell mortality. With regard to the CTX standard for these assays, we are aware that many CTXs and precursors of CTXs have been described (Atlantic, India and Pacific) still, our reference molecule in this case is CTX1B and it was used for this purpose in all the experiments.

Our ANCOVA analysis and post-hoc Tukey's H comparisons identified G. excentricus and G. australes, the two dominant species in the Canary Islands, [23], as producers of the highest levels of MTX like activity (Figure 4 and Tables 1 and 2). The differences in the MTX-like response between these two species and G. caribaeus, G. carolinianus and G. silvae were significant ( $p<0.05$; Table 2).

High levels of MTX-like activity by G. excentricus strain VGO791 from Tenerife (Canary Islands) were reported by Fraga et al. [45] who estimate for this strain a value of $600 \mathrm{pg}$ MTX eq cell ${ }^{-1}$. However, according to Pisapia et al. [46], the value estimated for the same strain, determined by ELA, was much lower ( $80 \mathrm{pg}$ MTX eq cell ${ }^{-1}$ ). In addition to the different assay methods, the discrepancies in the results may have been due to the use of a crude extract [45] vs. aqueous methanol extracts after 
liquid-liquid partitioning [46]. In agreement with Fraga et al. [45], we measured very high levels of MTX - like activity by strain VGO791. The discrepancy with the results of Pisapia, et al. [46] suggest that liquid-liquid partitioning did not achieve a complete separation of MTXs and CTXs. Our evaluation of MTX-like response in 18 other strains of G. excentricus from the Canary Islands (Tenerife, La Palma and La Gomera) also showed that MTX-like activity was highest in this species, followed by G. australes.

High levels of MTX-like toxicity, similar to those found in G. excentricus, were also measured in 30 strains of G. australes, from Tenerife, Lanzarote, Gran Canaria, El Hierro, Fuerteventura and La Gomera (Figure 4). These results are in agreement with the MTX-like toxicity determined by ELA for a strain of G. australes isolated in Hawaii [48], but not for G. australes strains VGO1178, VGO1181 (both from Tenerife, Atlantic Ocean) and CCMP1653 (Hawaii, Pacific Ocean) Pisapia et al. [46]. For the latter three strains, MTX-like toxicity levels were low and the strains were less maitotoxic than the strains of the species G. silvae, G. carolinianus and G. excentricus. Strains VGO1178 and VGO1181 were also analysed in the present study and their MTX-like toxicities were much higher than determined by Pisapia et al. [46]. However, the analyses were conducted more than 2 years apart, which together with other (e.g., environmental, methodological) factors may explain the disparity of the results.

MTX-like response was also detected in the other three species of Gambierdiscus evaluated in this work, G. caribaeus, G. silvae and G. carolinianus. The differences between these three Gambierdicus species were not significant ( $p>0.05$; Table 2$)$ and the levels were lower than those of G. excentricus and G. australes.

Literature reports suggest that MTX is of low oral toxicity and does not accumulate in fish flesh, but this conclusion is yet to be substantiated. Thus, whether MTX is able to induce CFP is unknown and need more investigation. A feeding study aimed at assessing MTX accumulation in the tissues of Pagrus auratus fed with G. australes showed the accumulation of MTX in the tissues of this carnivorous fish, including the viscera, liver and muscle [56]. Kohli et al. [56] reported that MTXs can accumulate in fish muscle. High MTX-type compounds levels were detected in microalgae from this study, especially in G. excentricus and G. australes. Therefore a considerable risk of presence of these very dangerous toxins in the flesh fish of Seriola spp. and Epinephelus spp. in the Canary Islands exists. Investigations of whether MTXs contribute to ciguatera outbreaks must therefore begin with determinations of the potential presence of these toxins in fish and their remnants, if available.

Among the species analysed in the present work, CTX-like response levels were highest in two strains of G. excentricus from La Gomera (VGO1361 and VGO1386, Figure 3). These results are in accordance with those reported for this species by other authors. For example, Litaker et al. [44] analysed eight Gambierdiscus species using a Neuro-2a assay and found that the most toxic was G. excentricus, specifically, a strain from Florida (USA). Also, in the above-described study by Fraga et al. very high levels of CTX-like activity were measured in a strain from Tenerife (VGO791). The high CTX-like response of G. excentricus is comparable to that of G. polynesiensis, the predominant CTX producer in the South Pacific [2,54].

In contrast to the consistent toxicity characteristics of G. excentricus, analyses of the toxicity of G. australes have yielded variable results. In our study, of the five analysed species, MTX activity was highest in G. australes and G. excentricus, but in three strains of G. australes CTX levels were $\sim$ ten-fold lower than those of the assayed G. excentricus strains. Pisapia et al. [46] also found a low range of CTX-like toxicity in three strains of G. australes differing in their origin (VGO1178 and VGO1181 from Canary Islands and CCMP1653 from Hawaii). Chinain et al. [2] reported comparatively low CTX-like toxicity for six G. australes strains originating from French Polynesia. Nishimura et al. [57] reported on a Japanese G. australes strain (S080911_1) with dichloromethane soluble fraction (DSF)—toxicity (Mousse bioassay, MBA) comparable to that of highly toxic G. polynesiensis species.

Only one strain of G. caribaeus, VGO1367, had a higher CTX-like toxicity than determined in other strains of the same species. This difference may reflect the different origin of the strains, as also observed in other species. For example, for two strains of G. excentricus from different sites (La Gomera Valle Rey-Ch. Condesa and La Gomera-San Sebastián), while high CTX-like toxicities characterised 
both, the respective values were markedly different. A comparison of those two strains with the published data of G. excentricus VGO791, from Tenerife Punta Hidalgo, also revealed considerable differences, as the latter strain has the highest toxicity detected thus far $\left(1050 \mathrm{fg}\right.$ CTX1B cell $\left.{ }^{-1}\right)$ [45]. For strains of G. australes and G. silvae, however, the CTX-like response level was not remarkably related to their origin. For G. carolinianus, only one strain from the Canary Islands (VGO1197) was available for our study, such that its origin-dependent variability could not be evaluated.

In summary, our findings clearly show differences in the toxicities of different microalgal species and in the distribution of Gambierdiscus species between islands of the Canary Islands [22]. Moreover, the differing toxicities of different strains of the same species highlight the need to assess intraspecific and geographic variations in the distribution of CTX and MTX toxicity. This information will facilitate determinations of the risk of ciguatera in the Canary Islands. Nonetheless, other factors must also be taken into account, including the behaviour patterns of the two main fish species linked to ciguatera outbreaks in the Canary Islands (Seriola spp. and Epinephelus spp.), the fishing effort, age of the fish and the depth of the fishing platform.

The next essential step to improve the knowledge about Ciguatera intoxication is undoubtedly the determination of toxin profiles in Gambierdiscus species, mainly G. excentricus and G. australes. It is also necessary to compare the toxin profiles of fish captured in the same area. This information would be very useful to relate the content of CTXs produced by different Gambierdiscus species with their presence in fish captured in a particular area.

\section{Conclusions}

In this work, CTX-like and MTX-like total toxicities were evaluated in a neuro-2a assay and an ELA, respectively. This approach confirmed previous results of the high-level risk of CFP posed by strains of G. excentricus. Among the strains estimated quantitatively for CTX-like toxicity, the levels were highest in those of G. excentricus (ranging between $128.2 \pm 25.68$ and $510.6 \pm 134.2 \mathrm{fg}$ CTX1B eq cell $\left.^{-1}\right)$, followed by G. carolinianus (100 $\left.\pm 18.05 \mathrm{fg} \mathrm{CTX1B} \mathrm{cell}^{-1}\right)$.

The results of our study seem to demonstrate the possible presence of MTXs in Gambierdiscus species from the Canary Islands, mainly G. australes. A determination of the presence and concentration of MTXs in fish is needed in order to establish whether safety measures aimed at protecting human health should be implemented. Our characterisation of the toxicity Gambierdiscus strains is an important contribution to improving ciguatera risk assessments in the Canary Islands region.

\section{Materials and Methods}

\subsection{Algal Cultures}

Micro-algal culture isolates of Gambierdiscus spp. $(n=67)$ used in the analysis belong to the Culture Collection of Harmful Microalgae of the Spanish Institute of Oceanography (CCVIEO). Sixty-three strains were sourced from seven different locations in the Canary Islands. However, since there was only one strain of G. carolinianus from the Canary Islands, four additional strains from Cuba were added to the analysis, VGO1397, CUB-9B5, CUB-9C6 and CUB-9C8, all of them were analysed by ELA and the VGO1397 strain was also analysed by Neuro-2A.

The five species analysed were G. australes $(n=28)$, G. excentricus $(n=17)$, G. caribaeus $(n=10)$, G. silvae $(n=7)$ and G. carolinianus $(n=5)$. They were cultured in flasks containing different volumes of $\mathrm{K} / 2$ medium without silicates and prepared in seawater from the Ría de Vigo, with the salinity adjusted to 35 . The cultures were incubated at $25{ }^{\circ} \mathrm{C}$ with a 12:12 L:D photoperiod.

Figure 1 shows all the species and strains from Canary Islands analysed as well as the type of analysis performed (ELA vs. Neuro-2a cell assay). 


\subsection{Neuro-2a Cell Assay}

Gambierdiscus spp. cultures were cultivated until a biomass of at least $1.5 \times 10^{6}$ cells was reached. Toxins were extracted following the method proposed by Caillaud et al. [3], with modifications. Briefly, the cells were harvested by filtration onto $47-\mathrm{mm}$ Whatmann filters and, under sonication ( $2 \mathrm{~min} /$ extraction, Footswitch 40 ), were extracted twice with equal volumes of methanol $(5 \mathrm{~mL}$ for $1 \times 10^{6}$ cells) and twice with equal volumes of aqueous methanol ( $\left.\mathrm{MeOH}: \mathrm{H}_{2} \mathrm{O} 50: 50\right)$ followed by centrifugation at $10,395 \times g$ for $10 \mathrm{~min}$. The four supernatants were pooled and frozen at $-20^{\circ} \mathrm{C}$ until used. A volume of $1 \mathrm{~mL}$ of the pooled sample was filtered through $0.45-\mu \mathrm{m}$ PTFE syringe filters and used for the Neuro-2a assay.

CTX-like toxicity was evaluated following the neuroblastoma cell-based (Neuro-2a) assay proposed by Caillaud et al. [49,58]. This assay measures cell viability of neuroblastoma cells (Neuro-2a) exposed to extracts when these extracts contain compounds that activate voltage gated sodium channels, that in the presence of ouabain and veratridine treatment cells die. Ouabain blocks the sodium and potassium ATPase pump inhibiting provoked efflux of sodium by compounds of the sample, and veratridine activates sodium compounds which increase and exacerbate the sodium levels.

Neuroblastoma murine cells (Neuro-2a) were obtained from the CIC cell bank of the University of Granada and maintained in RPMI-1640 medium (Gibco, Life Technologies, Carlsbad, CA, USA) supplemented with 5\% foetal bovine serum (Sigma-Aldrich, St. Louis, MO, USA), $1 \mathrm{mM}$ sodium pyruvate, $2.5 \mathrm{mg}$ L-glutamine $\mathrm{mL}^{-1}, 150$ units penicillin $\mathrm{mL}^{-1}$ and $50 \mu \mathrm{g}$ streptomycin $\mathrm{mL}^{-1}$ (Gibco Life Technologies, Carlsbad, CA), at $37^{\circ} \mathrm{C}$ in a $5 \% \mathrm{CO} 2$ humidified atmosphere, as previously described in Cañete and Diogéne [59].

Prior to the experiments, neuroblastoma cells were cultured in a 96-well microplate at $1.7 \times$ $10^{5}$ cells $\mathrm{mL}^{-1}$ and incubated for $24 \mathrm{~h}$ under the same conditions as described for cell maintenance. Thereafter, triplicate samples of the cells were exposed for $24 \mathrm{~h}$ to eight concentrations $(1 / 2$ serial dilutions) of CTX1B standard from the Pacific region (provided by R. Lewis [6]) or Gambierdiscus extracts (serial dilutions) with or without ouabain and veratridine $(\mathrm{O} / \mathrm{V}$ : to a final concentration of $0.14 \mathrm{mM}$ and $0.014 \mathrm{mM}$ respectively). In order to calibrate the experiments, the mean and standard deviation of the $\mathrm{IC}_{50}$ were estimated. Assays were done in triplicate. CTX-like toxicity was determined by measuring the cell viability using the colorimetric [3-(4,5-dimethylthiazol-2-yl)-2,5-diphenyltetrazolium] MTT (Sigma-Aldrich) [60] assay described in Manger et al. (1993) [61]. Absorbance was read at $570 \mathrm{~nm}$ using an automated multi-well scanning spectrophotometer (Biotek, Synergy HT, Winooski, VT, USA) and the results were expressed as a percentage of viability compared to the corresponding control (with and without $\mathrm{O} / \mathrm{V}$ ). The cell viability data were analysed using the statistical and programming software $\mathrm{R}$ 2.1.12 (R Foundation for Statistical Computing, Vienna, Austria, 2013) [62]. A dose-response curve fit with a sigmoid regression curve (with variable slope) was established for each experiment to estimate the concentration of Gambierdiscus extracts or standards that inhibited cell viability by $20 \%\left(\mathrm{IC}_{20}\right)$ and $80 \%\left(\mathrm{IC}_{80}\right)$ for each experimental condition (with and without $\left.\mathrm{O} / \mathrm{V}\right)$. Viabilities close to $50 \%\left(\mathrm{IC}_{50}\right)$ were further used as a toxicological parameter for qualitative and quantitative estimations of the content of CTX compounds produced, expressed as fg CTX1B equivalents (eq) per cell. The limit of detection was defined as the concentration inhibiting viability by $20 \%\left(\mathrm{IC}_{20}\right)$. Matrix effects of extracts were evaluated in wells lacking $\mathrm{O} / \mathrm{V}$. The CTX1B standard curve for this assay ranged from 25 to $0.2 \mathrm{pg} \cdot \mathrm{mL}^{-1}$.

\subsection{Erythrocyte Lysis Assay (ELA)}

Gambierdiscus strains from Canarias listed in Figure 1 and strains from Cuba detailed in 5.1 section were analysed by ELA. Aliquots of $3 \mathrm{~mL}$ and $10 \mathrm{~mL}$ were removed from each culture for cell counting and MTX extraction respectively. The samples to be counted were fixed in Lugol solution and counted in a Sedgewick Rafter cell chamber. MTX was extracted by centrifuging the $10-\mathrm{mL}$ aliquots at $2600 \times \mathrm{g}$ for $10 \mathrm{~min}$ at $4{ }^{\circ} \mathrm{C}$. The cell-free supernatants were carefully discarded and $1200 \mu \mathrm{L}$ of ELA buffer was added to the pelleted cells. These suspensions were transferred to 2-mL conical microcentrifuge tubes fitted with screw caps (Thermo Scientific, Waltham, MA, USA) and containing 0.5-mm glass 
beads (Soda Lime, Bio Spec Products, Inc., Bartlesville, OK, USA). Vigorous shaking of the samples for $20 \mathrm{~s}$ using a bead beater disrupted the cell membranes and released the cytoplasmic contents into the solution. Light microscopy observation was used to confirm that all cells were broken. The samples were maintained for $48 \mathrm{~h}$ at $4{ }^{\circ} \mathrm{C}$ until used in the assay.

Sheep blood in Alsever solution for use in the ELA was kindly provided by I. Manzano (CZ Veterinaria S.A., Porriño, Spain). Erythrocytes were separated from the plasma by centrifugation $\left(400 \times g, 10{ }^{\circ} \mathrm{C}, 10 \mathrm{~min}\right)$, washed twice with ELA buffer and then diluted in ELA buffer (1:99) at a final concentration of $\sim 1.7 \times 10^{7}$ red cells $\mathrm{mL}^{-1}$. The ELA was conducted using Riobó's method [63], modified as described by Holland et al. [48].

Each assay was carried out in triplicate in a 96-microwell plate by mixing $150 \mathrm{~mL}$ of blood with $150 \mathrm{~mL}$ of extract diluted in ELA buffer. Haemolysis controls for 0 and $100 \%$ lysis were prepared by mixing $150 \mu \mathrm{L}$ of erythrocyte suspension with $150 \mu \mathrm{L}$ of ELA buffer or distilled water, respectively. The microplates were incubated for $24 \mathrm{~h}$ at $4{ }^{\circ} \mathrm{C}$ after which the whole plate was centrifuged for $10 \mathrm{~min}$ at $400 \times \mathrm{g}$ at $4{ }^{\circ} \mathrm{C}$. From each well, $180 \mu \mathrm{L}$ of supernatant was transferred to a new plate and the absorbance at $405 \mathrm{~nm}$ was measured using a microplate reader (BioRad model 550, BioRad Laboratories, Hercules, CA, USA). Measurements from three replicates were averaged.

\subsection{Statistical Analysis}

An analysis of covariance (ANCOVA) was used to test the effect of Gambierdiscus species and cell abundance on the response variable (percent haemolysis). Post-hoc comparisons between Gambierdiscus species were carried out using Tukey's HSD. Normality, equal variance and the linearity assumptions of ANCOVA were previously checked.

All statistical analyses and graphic representations were performed using the statistical and programming software R 2.1.12 [62], packages 'multcomp' and 'marmap', available through the CRAN repository (www.r-project.org).

Author Contributions: Conceptualization, A.E.R. and P.R.; formal analysis, A.E.R.; A.T. and P.R..; data curation, P.A.D.; writing—original draft preparation, A.E.R. and P.R..; writing—review and editing, A.T.; I.B.; P.A.D. and J.D.; funding acquisition, I.B. All authors have read and agreed to the published version of the manuscript.

Funding: This work was funded by the Spanish national projects CICAN (CGL2013-40671-R) and DIANAS (CTM2017-86066-R) funded by Fecyt, 'Tropicalización y ciguatera en Canarias' funded by Fundación Biodiversidad and CCVIEO funded by Instituto Español de Oceanografía. In addition, it was supported by Europen project EuroCigua ('Risk characterization of ciguatera food poisoning in Europe' (GP/EFSA/AFSCO/2015/03). We want to acknowledge the URV-IRTA grant to Angels Tudó.

Acknowledgments: We are indebted to Isabel Manzano from CZ Veterinaria, S.A. who supplied us with the sheep blood for haemolytic assays. P.A. Díaz was supported by REDI170575 from the International Cooperation Programme of the Chilean National Commission for Scientific and Technological Research (CONICYT). This is a contribution of Unidad Asociada IEO-CSIC Microalgas Nocivas.

Conflicts of Interest: The authors declare no conflict of interest.

\section{References}

1. Adachi, R.; Fukuyo, Y. Thecal structure of a marine toxic dinoflagellate Gambierdiscus toxicus gen et sp-nov collected in a ciguatera-endemic area. Bull. Jpn. Soc. Sci. Fish 1979, 45, 67-71. [CrossRef]

2. Chinain, M.; Darius, H.T.; Ung, A.; Cruchet, P.; Wang, Z.; Ponton, D.; Laurent, D.; Pauillac, S. Growth and toxin production in the ciguatera-causing dinoflagellate Gambierdiscus polynesiensis (Dinophyceae) in culture. Toxicon 2010, 56, 739-750. [CrossRef]

3. Caillaud, A.; De la Iglesia, P.; Barber, E.; Eixarch, H.; Mohammad-Noor, N.; Yasumoto, T.; Diogène, J. Monitoring of dissolved ciguatoxin and maitotoxin using solid-phase adsorption toxin tracking devices: Application to Gambierdiscus pacificus in culture. Harmful Algae 2011, 10, 433-446. [CrossRef]

4. Fusetani, N.; Kem, W. Marine toxins: An overview. Prog. Mol. Subcell. Biol. 2009, 46, 1-44. 
5. Yasumoto, T.; Nakajima, I.; Bagnis, R.; Adachi, R. Finding of a dinoflagellate as a likely culprit of ciguatera. Bull. Jpn. Soc. Sci. Fish 1977, 43, 1021-1026. [CrossRef]

6. Lewis, R.J.; Sellin, M.; Poli, M.A.; Norton, R.S.; MacLeod, J.K.; Sheil, M.M. Purification and characterization of ciguatoxins from moray eel (Lycodontis javanicus, Muraenidae). Toxicon 1991, 29, 1115-1127. [CrossRef]

7. Alfonso, A.; Roman, Y.; Vieytes, M.R.; Ofuji, K.; Satake, M.; Yasumoto, T.; Botana, L.M. Azaspiracid-4 inhibits Ca2+ entry by stored operated channels in human T Iymphocytes. Biochem. Pharmacol. 2005, 69, 1543-1680. [CrossRef]

8. Ikehara, T.; Kuniyoshi, K.; Oshiro, N.; Yasumoto, T. Biooxidation of ciguatoxins leads to species-specific toxin profiles. Toxins 2017, 9, 205. [CrossRef]

9. Yasumoto, T. Chemistry, etiology, and food chain dynamics of marine toxins. Proc. Jpn. Acad. Ser B Phys. Biol. Sci. 2005, 81, 43-51. [CrossRef]

10. EFSA Panel on Contaminants in the Food Chain. Scientific Opinion on marine biotoxins in shellfish-Emerging toxins: Ciguatoxin group. EFSA J. 2010, 8. [CrossRef]

11. Lewis, R.J. Ciguatera: Australian perspectives on a global problem. Toxicon 2006, 48, 799-809. [CrossRef]

12. Skinner, M.P.; Brewer, T.D.; Johnstone, R.; Fleming, L.E.; Lewis, R.J. Ciguatera Fish Poisoning in the Pacific Islands (1998 to 2008). PLoS Negl. Trop. Dis. 2011, 5, e1416. [CrossRef]

13. Kohli, G.S.; Murray, S.A.; Neilan, B.A.; Rhodes, L.L.; Harwood, D.T.; Smith, K.F.; Meyer, L.; Capper, A.; Brett, S.; Hallegraeff, G.M. High abundance of the potentially maitotoxic dinoflagellate Gambierdiscus carpenteri in temperate waters of New South Wales, Australia. Harmful Algae 2014, 39, 134-145. [CrossRef]

14. Larsson, M.E.; Laczka, O.F.; Harwood, D.T.; Lewis, R.J.; Himaya, S.W.A.; Murray, S.A.; Doblin, M.A. Toxicology of Gambierdiscus spp. (Dinophyceae) from tropical and temperate Australian Waters. Mar. Drugs 2018, 16, 7. [CrossRef]

15. Gouveia, N.N.; Vale, P.; Gouveia, N.; Delgado, J. Primeiro registo da ocorrencia de episódios do tipo ciguatérico no arquipé lago da Madeira. In Proceedings of the Algas Tóxicas e Biotoxinas nas aguas da Península Ibérica 2009, IPIMAR, Lisboa, Portugal, 12-15 May 2009; pp. 152-157.

16. Otero, P.; Pérez, S.; Alfonso, A.; Vale, C.; Rodríguez, P.; Gouveia, N.N.; Gouveia, N.; Delgado, J.; Vale, P.; Hirama, M.; et al. First toxin profile of Ciguateric fish in Madeira Arquipelago (Europe). Anal. Chem. 2010, 82, 6032-6039. [CrossRef]

17. Costa, P.R.; Estevez, P.; Castro, D.; Soliño, L.; Gouveia, N.; Santos, C.; Rodrigues, S.M.; Leao, J.M.; Gago-Martínez, A. New Insights into the occurrence and toxin Profile of Ciguatoxins in Selvagens Islands (Madeira, Portugal). Toxins 2018, 10, 524. [CrossRef]

18. Sanchez-Henao, J.A.; García-Álvarez, N.; Fernández, A.; Saavedra, P.; Silva Sergent, F.; Padilla, D.; Acosta-Hernández, B.; Martel Suárez, M.; Diogène, L.; Real, F. Predictive score and probability of CTX-like toxicity in fish samples from the official control of ciguatera in the Canary Islands. Sci. Total Environ. 2019, 673, 576-584. [CrossRef]

19. Pérez-Arellano, J.L.; Luzardo, O.P.; Brito, A.P.; Cabrera, M.H.; Zumbado, M.; Carranza, C.; Angel-Moreno, A.; Dickey, R.W.; Boada, L.D. Ciguatera fish poisoning, Canary Islands. Emerg. Infect. Dis. 2005, 11, 1981-1982. [CrossRef]

20. Boada, L.D.; Zumbado, M.; Almeida-Gonzalez, M.; Plakas, S.M.; Granade, H.R.; Abraham, A.; Jester, E.L.E.; Dickey, R.W. Ciguatera fish poisoning on the West Africa Coast: An emerging risk in the Canary Islands (Spain). Toxicon 2010, 56, 1516-1519. [CrossRef]

21. Bravo, J.; Cabrera, F.; Vega, B.; Romásn, E.; Martel, M.; Acosta, F. Appearance of ciguatoxin fish in atlantic europe waters. World Acad. Sci. Eng. Technol. Med Health Sci. 2015, 2, $2-23$.

22. Rodríguez, F.; Fraga, S.; Ramilo, I.; Rial, P.; Figueroa, R.I.; Riobó, P.; Bravo, 1. Canary Islands (NE Atlantic) as a biodiversity 'hotspot' of Gambierdiscus: Implications for future trends of ciguatera in the area. Harmful Algae 2017, 67, 131-143. [CrossRef] [PubMed]

23. Bravo, I.; Rodríguez, F.; Ramilo, I.; Rial, P.; Fraga, S. Ciguatera-causing dinoflagellate Gambierdiscus spp. (Dinophyceae) in a subtropical region of North Atlantic Ocean (Canary Islands): Morphological characterization and biogeography. Toxins 2019, 11, 423. [CrossRef] [PubMed]

24. Scheuer, P.J.; Takahashi, W.; Tsutsumi, J.; Yoshida, T. Ciguatoxin: Isolation and chemical nature. Science 1967, 155, 1267-1268. [CrossRef] 
25. Murata, M.; Legrand, A.M.; Ishibashi, Y.; Yasumoto, T. Structures of ciguatoxin and its congener. J. Am. Chem. Soc. 1989, 111, 8929-8931. [CrossRef]

26. Strachan, L.C.; Lewis, R.J.; Nicholson, G.M. Differential actions of pacific ciguatoxin-1 on sodium channel subtypes in mammalian sensory neurons. J. Pharmacol. Exp. Ther. 1999, 288, 379-388.

27. Vetter, I.; Touska, F.; Hess, A.; Hinsbey, R.; Sattler, S.; Lampert, A.; Zimmermann, K. Ciguatoxins activate specific cold pain pathways to elicit burning pain from cooling. EMBO J. 2012, 31, 3795-3808. [CrossRef]

28. Ohizumi, Y.; Yasumoto, T. Contraction and increase in tissue calcium content induced by maitotoxin, the most potent known marine toxin, in intestinal smooth muscle. Br. J. Pharmacol. 1993, 79, 3-5. [CrossRef]

29. Murata, M.; Naoki, H.; Matsunaga, S.; Satake, M.; Yasumoto, T. Structure and partial stereochemical assignments for maitotoxin, the most toxic and largest natural Non-biopolymer. J. Am. Chem. Soc. 1994, 116, 7098-7107. [CrossRef]

30. Lundy, P.M.; Nelson, P.; Mi, L.; Frew, R.; Minaker, S.; Vair, C.; Sawyer, T.W. Pharmacological differentiation of the P2X7 receptor and the maitotoxin-activated cationic channel. Eur. J. Pharmacol. 2004, 487, 17-28. [CrossRef]

31. Frew, R.; Wang, Y.; Weiss, T.M.; Nelson, P.; Sawyer, T.W. Attenuation of maitotoxin-induced cytotoxicity in rat aortic smooth muscle cells by inhibitors of $\mathrm{Na}+/ \mathrm{Ca}^{2+}$ exchange, and calpain activation. Toxicon 2008, 51, 1400-1408. [CrossRef]

32. Wang, Y.; Weiss, M.T.; Yin, J.; Frew, R.; Tenn, C.; Nelson, P.P.; Vair, C.; Sawyer, T.W. Role of the sodium hydrogen exchanger in maitotoxin-induced cell death in cultured rat cortical neurons. Toxicon 2009, 54, 95-102. [CrossRef] [PubMed]

33. Yokoyama, A.; Murata, M.; Oshima, Y.; Washita, T.; Yasumoto, T. Some chemical properties of maitotoxin, a putative calcium channel agonist from a marine dinoflagellate. J. Biochem. 1988, 104, 184-187. [CrossRef] [PubMed]

34. Munday, R. Toxicology of seafood toxins: A critical review. In Seafood and Freshwater Toxins, Pharmacology, Physiology and Detection; Botana, M.L., Ed.; CRC Press: Boca Raton, FL, USA, 2014; pp. 197-290.

35. Yasumoto, T.; Hashimoto, Y.; Bagnis, R.; Randall, J.E.; Banner, A.H. Toxicity of the surgeonfishes. Bull. Jpn. Soc. Sci. Fish 1971, 37. [CrossRef]

36. Yasumoto, T.; Bagnis, R.; Vernoux, J.P. Toxicity of the surgeon fishes: II. Properties of the principal water soluble toxin. Bull. Jpn. Soc. Sci. Fish 1976, 42, 359-365. [CrossRef]

37. Kretzschmar, A.L.; Verma, A.; Kohli, G.; Murray, S. Development of a quantitative PCR assay for the detection and enumeration of a potentially ciguatoxin-producing dinoflagellate, Gambierdiscus lapillus (Gonyaulacales, Dinophyceae). PLOS ONE 2019, 14, e0224664. [CrossRef]

38. Murray, J.M.; Boundy, M.J.; Selwood, A.I.; Harwood, D.T. Development of an LC-MS/MS method to simultaneously monitor maitotoxins and selected ciguatoxins in algal cultures and P-CTX-1B in fish. Harmful Algae 2018, 80, 80-87. [CrossRef]

39. Yogi, K.; Oshiro, N.; Inafuku, Y.; Hirama, M.; Yasumoto, T. Detailed LC-MS/MS analysis of ciguatoxins revealing distinct regional and species characteristics in fish and causative alga from the Pacific. Anal. Chem. 2011, 83, 886-8891. [CrossRef]

40. Roeder, K.; Erler, K.; Kibler, S.; Tester, P.; Van The, H.; Nguyen-Ngoc, L.; Gerdts, G.; Luckas, B. Characteristic profiles of Ciguatera toxins in different strains of Gambierdiscus spp. Toxicon 2010, 56, 731-738. [CrossRef]

41. Paz, B.; Riobó, P.; Franco, J.M. Preliminary study for rapid determination of phycotoxins in microalgae whole cells using matrix assisted laser desorption/ionization time of flight mass spectrometry. Rapid Commun. Mass Spectrom. 2011, 25, 3627-3639. [CrossRef]

42. Stewart, I.; Eaglesham, G.K.; Poole, S.; Graham, G.; Paulo, C.; Wickramasinghe, W.; Sadler, R.; Shaw, G.R. Establishing a public health analytical service based on chemical methods for detecting and quantifying Pacific ciguatoxin in fish samples. Toxicon 2010, 56, 804-812. [CrossRef]

43. Kohli, G.S.; Haslauer, K.; Sarowar, C.; Kretzschmar, A.L.; Boulter, M.; Harwood, T.; Laczka, O.; Murray, S.A. Qualitative and quantitative assessment of the presence of Ciguatoxin, P-CTX-1B, in Spanish Mackerel (Scomberomorus commerson) from waters in New SouthWales (Australia). Toxicol. Rep. 2017, 4, 328-334. [CrossRef] [PubMed]

44. Litaker, R.W.; Holland, W.C.; Hardison, D.R.; Pisapia, F.; Hess, P.; Kibler, S.R.; Tester, P.A. Ciguatoxicity of Gambierdiscus and Fukuyoa species from the Caribbean and Gulf of Mexico. PLoS ONE 2017, 12, e0185776. [CrossRef] [PubMed] 
45. Fraga, S.; Rodríguez, F.; Caillaud, A.; Diogène, J.; Raho, N.; Zapata, M. Gambierdiscus excentricus sp. nov. (Dinophyceae): A benthic toxic dinoflagellate from the Canary Islands (NE Atlantic Ocean). Harmful Algae 2011, 11, 10-22. [CrossRef]

46. Pisapia, F.; Holland, W.C.; Hardison, D.R.; Litaker, R.W.; Fraga, S.; Nishimura, T.; Masao Adachi, M.; Nguyen-Ngoc, L.; Séchet, V.; Amzil, Z.; et al. Toxicity screening of 13 Gambierdiscus strains using neuro-2a and erythrocyte lysis bioassays. Harmful Algae 2017, 63, 173-183. [CrossRef]

47. Reverté, L.; Toldrà, A.; Andre, K.B.; Fraga, S.; de Falco, G.; Campàs, M.; Diogène, J. Assessment of cytotoxicity in ten strains of Gambierdiscus australes from Macaronesian Islands by neuro-2a cell-based assays. J. Appl. Physiol. 2018, 30, 2447-2461. [CrossRef]

48. Holland, W.C.; Litaker, R.W.; Tomas, C.R.; Kibler, S.R.; Place, A.R.; Davenport, E.D.; Tester, P.A. Differences in the toxicity of six Gambierdiscus (Dinophyceae) species measured using an in vitro human erythrocyte lysis assay. Toxicon 2013, 65, 15-33. [CrossRef]

49. Caillaud, A.; Eixarch, H.; de la Iglesia, P.; Rodriguez, M.; Dominguez, L.; Andree, K.B.; Diogène, J. Towards the standardisation of the neuroblastoma (neuro-2a) cell-based assay for ciguatoxin-like toxicity detection in fish: Application to fish caught in the Canary Islands. Food Addit. Contam. Part A 2012, 29, 1000-1010. [CrossRef]

50. Pisapia, F.; Sibat, M.; Herrenknecht, C.; Lhaute, K.; Gaiani, G.; Ferron, P.J.; Fessard, V.; Fraga, S.; Nascimento, S.M.; Litaker, R.W.; et al. Maitotoxin-4, a Novel MTX analog produced by Gambierdiscus excentricus. Mar. Drugs 2017, 15, 220. [CrossRef]

51. Pawlowiez, R.; Darius, H.T.; Cruchet, P.; Rossi, F.; Caillaud, A.; Laurent, D.; Chinain, M. Evaluation of seafood toxicity in the Australes archipelago (French Polynesia) using the neuroblastoma cell-based assay. Food Addit. Contam. Part A 2013, 30, 567-586. [CrossRef]

52. Diogène, J.; Reverté, L.; Rambla-Alegre, M.; del Río, V.; de la Iglesia, P.; Campàs, M.; Palacios, O.; Flores, C.; Caixach, J.; Ralijaona, C.; et al. Identification of ciguatoxins in a shark involved in a fatal food poisoning in the Indian Ocean. Sci. Rep. 2017, 7, 8240. [CrossRef]

53. Reverté, L.; Solino, L.; Carnicer, O.; Diogène, J.; Campàs, M. Alternative methods for the detection of emerging marine toxins: Biosensors, biochemical assays and cell-based assays. Mar. Drugs 2014, 12, 5719-5763. [CrossRef] [PubMed]

54. Rhodes, L.; Harwood, T.; Smith, K.; Argyle, P.; Munday, R. Production of ciguatoxin and maitotoxin by strains of Gambierdiscus australes, G. pacificus and G. polynesiensis (Dinophyceae) isolated from Rarotonga, Cook Islands. Harmful Algae 2014, 39, 185-190. [CrossRef]

55. Munday, R.; Murray, S.; Rhodes, L.L.; Larsson, M.E.; Harwood, D.T. Ciguatoxins and maitotoxins in extracts of sixteen Gambierdiscus isolates and one Fukuyoa isolate from the South Pacific and their toxicity to mice by intraperitoneal and oral administration. Mar. Drugs 2017, 15, 208. [CrossRef] [PubMed]

56. Kohli, G.S.; Giménez, G.; Rhodes, L.; Harwood, T.; Selwood, A.; Jerrett, A.; Murray, S.; Neilan, B. A feeding study to probe the uptake of Maitotoxin by snapper (Pagrus auratus). Harmful Algae 2014, 37, 125-132. [CrossRef]

57. Nishimura, T.; Sato, S.; Tawong, W.; Sakanari, H.; Uehara, K.; Mahfusur, M.; Shah, R.; Suda, S.; Yasumoto, T.; Taira, Y.; et al. Genetic diversity and distribution of the Ciguatera-causing dinoflagellate Gambierdiscus spp. (Dinophyceae) in coastal areas of Japan. PLoS ONE 2013, 8, e60882. [CrossRef] [PubMed]

58. Caillaud, A.; De la Iglesia, P.; Darius, H.; Pauillac, S.; Aligizaki, K.; Fraga, S.; Chinain, M.; Diogène, J. Update on methodologies available for ciguatoxin determination: Perspectives to confront the onset of Ciguatera Fish Poisoning in Europe. Mar. Drugs 2010, 8, 1838-1907. [CrossRef]

59. Cañete, E.; Diogéne, J. Comparative study of the use of neuroblastoma cells (Neuro-2a) and neuroblastoma $\times$ glioma hybrid cells (NG108-15) for the toxic effect quantification of marine toxins. Toxicon 2008, 52, 541-550. [CrossRef]

60. Mosmann, T. Rapid colorimetric assay for cellular growth and survival: Application to proliferation and cytotoxicity assays. J. Immunol. Methods 1993, 65, 55-63. [CrossRef]

61. Manger, R.L.; Leja, L.S.; Lee, S.Y.; Hungerford, J.M.; Wekell, M.M. Tetrazolium-based cell bioassay for neurotoxins active on voltage-sensitive sodium channels: Semiautomated assay for saxitoxins, brevetoxins, and ciguatoxins. Anal. Biochem. 1993, 214, 190-194. [CrossRef] 
62. R Development Core Team. R: A Language and Environment for Statistical Computing; R Foundation for Statistical Computing: Vienna, Austria, 2013; ISBN 3-900051-07-0.

63. Riobó, P.; Paz, B.; Franco, J.M.; Vázquez, J.A.; Murado, M.A. Proposal for a simple and sensitive haemolytic assay for palytoxin. Toxicological dynamics, kinetics, ouabain inhibition and thermal stability. Harmful Algae 2008, 7, 415-429. [CrossRef] 